\title{
Teachers' Conceptions of the CLT Approach in English Language Education
}

\section{Sureepong Phothongsunan}

\author{
School of Arts, \\ Assumption University, \\ Thailand
}

DOI: https://doi.org/10.36941/jesr-2020-0071

\begin{abstract}
The communicative language teaching (CLT) approach and its fundamental principles, including learning to communicate through interaction and engagement, are generally upheld by theories in the area of second language acquisition even though by and large implementing CLT is to some degree difficult and ineffective in many ESL (English as a second language) and EFL (English as a foreign language) contexts. This action research is undertaken to assist a small group of Thai EFL school teachers in developing and implementing context-sensitive CLT through a teacher training program designed for their own professional development as secondary school teachers. Two methods are employed, an observation and a task evaluation. It is found that from the teachers' practice using CLT in teaching, their classes are hardly communicative in nature as communication is constrained and rather unilateral, mostly directed by the teachers. Some recommendations are made to the teachers under study based on the methods used, addressing fluency rather than accuracy if students' communicative competence is the goal.
\end{abstract}

Keywords: Communicative language teaching (CLT), contexts, EFL teachers

\section{Introduction}

The communicative approach (CA), in common with CLT and task-based language teaching (TBLT), has been corroborated by a number of ELT (English language teaching) practitioners in the past few decades. Interestingly, substantial research conducted in various EFL settings worldwide points to the difficulties of implementing CLT. In Thailand, this has also been the case in secondary schools where attempts to undertake CLT have not proven satisfactory.

The CA in truth emerged as a combination of two strands of thought. The first dealt with the rules of use and the second indicated that if the activities used by the language teacher were directed at involving the learners in solving communication difficulties in the target language, then language learning occurred per se (Allwright, 1979). As a result, instead of teaching grammar structures through a process between audiolingualism and PPP (presentation, practice, and production), the teacher could teach various language functions, spend time having the learners discuss and share ideas and do role-plays. In the first place, the communicative approach indeed brought about a phenomenon of role-plays and information gap activities, which attempted to provoke actual necessary communication and interaction. It would appear that for some of the students who preferred grammar learning, this could mean a conflict they had to face. Though grammar teaching 
still took place, more time was spent on discussions and dialogs and other communicative tasks.

In ELT, there are teaching practices that come with teaching methods including the CLT approach. This entire teaching procedure is a rather complex event that relies on different aspects, including the teacher's teaching behavior, the managerial and social context of the tasks, personal opinions and habits and the students' expectancy (Brumfit, 1994). Also, classroom activities are supported by the teacher in diverse features whilst the teacher concentrates more on student participation through independent learning. The highlight of communicative interaction is more chances for building cooperative connections between the teacher and students and among students who have more opportunities to express their own identity in the classroom. With classroom activities in groups and pairs, students can communicate with the teacher independently. Also, learners' errors are not being continuously corrected in communicative skill improvement.

In this regard, it is important to focus on EFL teachers who play a vital role because the language of EFL teachers is an essential part of the learners' input. Furthermore, EFL teachers are usually perceived as role models who have fluent English competence and employ various communication strategies to help students learn and improve their English (Zheng. 2004).

In this study, two main research questions include:

1. What is Thai EFL teachers' understanding of the communicative language teaching (CLT) approach?

2. How do they evaluate learners' tasks using CLT in their teaching practice?

\section{Literature Review}

In the area of teaching approaches, CLT is regarded as one effective method and the main notion of CLT is communicative competence which aims to help learners achieve their communicative ability (Richards \& Rodgers, 2014). CLT, as an approach rather than a method, comprises several sets of principles regarding the communicative language purposes and language learning and can be implemented to promote a wide variety of classroom processes.

The objective of CLT is to improve learners' ability to use the target language in real-life situations (Celce-Murcia, 2001). It requires a new design for a teaching method, teaching materials, the roles and performances of teachers and learners and communicative activities and techniques in the classroom (Richards, \& Rodgers, 2014). CLT allows the learners to perform actively in L2. In fact, it is not quite distinct from the previous method, the audiolingual or oral-situational method which aims to improve the learners' performance to communicate. However, CLT focuses more on divergent language patterns. To elaborate, the former method highlights a group of linguistic systems (phonological, lexical, and grammatical), meanwhile CLT concentrates on language functional patterns and communicative competence theory (Ellis, 2003). It is an approach to language teaching that emphasizes authenticity, interaction, student-centered learning, task-based activities, and communication for the real world and meaningful purposes (Brown, 2007). In short, CLT can be defined as an approach in language teaching that aims to facilitate the learners to have communicative competence and use the language in the authentic situations.

Simply put, in CLT, learners are encouraged to focus on meaning rather than form for the communicative events (Savignon, 2006). As Dörnyei \& Ushioda (2009) point out, the concept in learning through the communicative approach makes certain that the communicative ability of learners should improve automatically when they actively participate in meaningful communicative activities. Brown (2007) also proposes four underlying characteristics of CLT: communicative competence, engagement in real language-use, fluency over accuracy and productive language use.

\subsection{Communicative Competence}

Young (2008) defines competence as something that an individual possesses more or less than another person, and a person's competence is a multifaceted construct composed of several parts. 
The conception of communicative competence is complicated and remains unstable because it covers topics within discourse analysis, pragmatics, and the theory of grammar (Widdowson, 2003). Similarly, Shrum and Glisan (2005) see it as the capability to function in a communicative setting by using not only grammatical knowledge but also non-verbal communication and intonation, strategies, and risk-taking in endeavoring communication.

\section{CLT Classroom Activities Promoting Communication}

In CLT classrooms, it is necessary to provide students more opportunities to have English practice to enhance communicative skills and participate in authentic communicative situations. The teacher has to design their classroom activities to promote the interaction and the learning outcome of the students. One method to make the class more effective is to use different tasks to engage students in classroom interaction. According to Ellis (2003), tasks are activities that call for primarily meaningfocused language use where the students are required to perform tasks as language users in terms of manipulating the similar types of communicative procedures as they participate in the real-world performances. This way, tasks resemble the contexts that students can use in their daily life.

The classroom is the unique context where communication exists as the meanings and the structures of communication are shaped by teachers and students' performances, perceptions, and settings within the classroom (Johnson, 1996). However, many EFL teachers in higher education encounter problems in teaching English in the classroom because of students' low English speaking proficiency. Regarded as active or productive skill, speaking is needed in communicative activities that contribute to students' use of the language. Speaking is essential because it is a part of the communal social activity (Luoma, 2004). Speaking ability is also the considerable part of language curriculums and it serves as the significant aspect of language assessment.

For classroom activities, Richards and Rodgers (2014) justify that teachers are more motivated to create small-group work. Small-group activities are beneficial for communicative classroom purposes. The small groups in language classrooms benefit students to promote more participation. Moreover, these activities allow more room for the teachers to give feedback, observe and provide adequate advice to the students. The pair and group activities offer learners a great chance to use the language and to improve fluency.

To achieve in the language classroom, Littlewood (2007) summarizes the significance of communicative activities towards language learning. The communicative activities provide wholetask practice, improve motivation, allow natural learning and create a context which supports learning. These activities are essential elements of students' learning process. Celce-Murcia (2001) suggests activities that promote oral skills, including discussions, speeches, role plays, conversations, oral dialogue journals, and other accuracy-based activities. Specifically, Richards and Rodgers (2014) point out that common activities in CLT involve jig-saws, task-completion, information-gathering, opinion-sharing, information-transfer, reasoning gap and role plays. These activities can promote students' opportunities to use language in various tasks. A broader category of communicative activities is proposed by Ellis (2003), such as field experiences, classroom management activities, inviting guest speakers, discussing students' personal life topics and other topics from other subjects in the program.

In brief, all activities for CLT are designed to serve the learners' communicative competence, which includes group work and pair work activities in promoting classroom interaction.

Today, English communication is the medium among people worldwide. Thus, it is clearly important to have communicative language ability. EFL students, and teachers alike, likewise should have communicative English ability because it can help them communicate successfully and for students communicative skill aims and prepares them to communicate effectively in the digital world. Rubin and Thompson (1994) recommended how to communicate efficiently, indicating that one should have knowledge beyond grammar, vocabulary and the way of making sentences. Significantly, in the professional world, graduates' proficient communicative skills are required more 
and more by today's employers than their outstanding academic records (Ward, 2017).

\section{Methods}

Employing an interpretive approach using mixed methods, this research aims to provide a better understanding of the intricacies of the social world, focusing on the ability of those who create meanings to the world they live in.

The methods used to obtain data are an observation and a task evaluation. By combining these two methods, the researcher gains better understanding and substantiation as these methods compliment and supplement each other. To evaluate the development of EFL teachers' knowledge of CLT, a systematic observation scheme was first generated after the participating teachers were informed of what CLT and task-based language teaching (TBLT) mean. The key principles related were also identified to the participants in relation to second language learning and cognitive psychology. Then, the researcher's developed scheme was compared with other typical CLT observation schemes. Teacher talk and peer work represent two key elements of CLT to assess pedagogical activities in the classrooms to the extent that there is a primary focus on meaning and of how classroom interaction and engagement are observed.

Also, an additional criterion for evaluating a task was given to the extent that there is a communicative goal set for learners to accomplish. In sum, these three criteria were mainly considered in the analysis of classroom talk and pair or group work and in the plan for and the process of pedagogical undertakings.

The observed classes were video-taped separately with the consent of the teachers and students and each one lasted about thirty minutes. Field notes were also taken during each observation. Each class had bout ten to fifteen students. Afterwards, the interactions between the teachers and students were transcribed. In observing pair and group activities, the students' behaviors and the teachers' use of strategies to increase the students' engagement and the circumstances where these occurred were also noted. The researcher analyzed the data obtained to find patterns or features of the teachers' practice after that the researcher applied these patterns or features to the conceptual framework of this study.

\subsection{Participants}

Eight Thai EFL secondary school teachers from a private school in Bangkok were selected purposively as participants in this study. Six were female teachers while the two others were male. They had been teaching English at the school, ranging from three to sixteen years and their age varied from twenty six to forty five. Six had a Master's degree in English or English Language Teaching whereas the two others held a Bachelor's degree in Curriculum and Instruction or Education Administration. It was found that five had some experience training on teaching English at school and in English speaking countries; however, three teachers reported having some ELT training at school only.

\section{Findings and Discussion}

By means of analysis with an interpretive and inductive approach, the scheme essentially captured insights into the teachers' practice and their underlying beliefs. In a casual focus group interview conducted prior to observations, the teachers had claimed that they were using CLT to some degree. Nonetheless, in the initial observations, some inconsistencies between their reported beliefs and actual practice were revealed. Even though the teachers had very different teaching styles and paces, there were some common features which resulted in constrained communication and engagement. These include weak teacher enquiring and unfitting talk administration as presented in Table 1 below. 
Table 1: Attributes contributing to communication constraints

\begin{tabular}{|l|l|l|}
\hline Standard Feature & Teacher Enquiry & Talk Administration \\
\hline $\begin{array}{l}\text { Initial Emphasis } \\
\text { on Meaning }\end{array}$ & $\begin{array}{l}\text {-Posed display questions which they } \\
\text { already knew the answers to regularly }\end{array}$ & $\begin{array}{l}\text {-Hardly gave feedback on content } \\
\text {-Disrupted the conversation flow by rectifying } \\
\text { students' mistakes occasionally }\end{array}$ \\
\hline $\begin{array}{l}\text { Engagement and } \\
\text { Interaction }\end{array}$ & $\begin{array}{l}\text {-Teacher turns exceeded student turns } \\
\text {-Primarily teacher initiative and focused }\end{array}$ & $\begin{array}{l}\text {-Limited response time given for students } \\
\text {-Ignored students' responses if not the standard } \\
\text { answer in the teacher's thought or in the text }\end{array}$ \\
\hline
\end{tabular}

An appraisal of teacher questioning or asking indicates that the way the teachers questioned the students does not show a primary focus on meaning. They mainly asked displayed questions. Display questions are questions asked to see if the persons spoken to know the answer or not. In an ELT classroom, these questions are used by teachers asking learners to see if they understand or remember something. Display questions can actually be compared to referential questions, asked when questioners need to know the answer. Display questions evidently lack the communicative feature and validity of referential questions; however, they appear to be an important instrument in the classroom, not only for the teacher to be able to check and evaluate their learners' comprehension, but also as a basis for listening practice. The teachers in this study seemed to have a misconception that this type of questioning promotes real communication. For example, when one of the teachers pointed to a thing in the picture to ask, 'What do you call this?, the class was actually practicing the sentence structure related to objects or items found in a house. Teachers should realize that this type of questioning is similar to form-focused practice (Thornbury, 1996). The explicit teaching mode observed contributes less to learners' ability to use the form with accuracy in production. Thus, meaning-focused instruction should be used alongside as well (Ellis, 2003).

It can be pointed out that instead of only asking display questions, CLT teachers are recommended to ask referential questions, using why and how to gain open-ended, unexpected responses from students. These referential questions create co-constructed meaning in the flow of interaction, and it is indeed this co-constructed meaning that has the potential for learning to occur (Long, 200o). Secondly, using referential questions to relate topics or contents to learners' own experience is always a useful strategy to raise students' desire to engage. They are usually more interested in these personalized questions. Thus, when they participate in meaningful communication, they can learn to communicate.

In terms of task evaluation, the teachers did clearly have communicative goals set for learners to achieve in their lesson plans. Nonetheless, it was found that they in most cases failed to come up with clear assessment criteria to evaluate learners' success in using CLT after the classes were taught. It can be said that communicative activities based on fluency and accuracy should be employed. Brumfit (1994) suggests that evaluation is associated with accuracy, problem solving and evidence of skill mastering. On the other hand, the use of language still needs fluency, expressiveness, a reliance on implicit knowledge, and naturalness in terms of understanding or production.

As observed from their teachings, the teachers obstructed the students' conversation flow by correcting students' language production. In communicative activities, teachers should not be strict with students' errors but rather encourage them to speak more confidently in the class. Lu and $\mathrm{Ng}$ (2013) remark that errors produced by students in the CLT class are acceptable and fluency frequently dominates accuracy. In principle, learning a language is originally served for oral communication in utilizing the language; therefore, ignorance of errors allows learners to try out the target language to improve their communicative competence. In addition, Larsen-Freeman (2000) states that errors of the form can be tolerated during fluency-based activities and are seen as a natural outcome of the development of communication skills.

As noted by Johnson (1996), for the teachers who aim to accommodate their students to have communicative competence in the classroom, they need to provide communication structures that 
maximize the linguistic and interactional proficiency of the students to afford their opportunities to engage in and learn from classroom activities. It can be accomplished by expressing or setting the linguistic, social, and interactional norms that control the students to participate in classroom activities.

In the CLT classroom, teachers can focus more on fluency rather than accuracy if they intend to improve students' communicative competence. They can provide feedback or correct errors made by students after the conversation practice is complete. In this case, students can gradually learn how to use the language grammatically and meaningfully.

Another arising issue deals with giving students more air time to interact or engage back. Teachers can simply increase students' turns by giving them more time to respond to their questions. To do so, teachers may need to force themselves to tolerate any silence in the interaction. It is not difficult to recognize those features which lead to low learner engagement. Nonetheless, teachers may not be well aware when these emerge in their own practice, causing minimal to no involvement from learners.

Last but not least, if a well-developed lesson plan always fails to succeed in teaching communicatively, teachers should consider implementing a technological tool in the CLT classroom which could help improve and motivate students' interest (Somdee and Suppasetseree, 2012). Webbased projects, online self-tests, and electronic portfolios are some of the activities that can be used to supplement teaching and learning (Kreiger, 2005). Different kinds of teaching materials can promote students to be more enthusiastic and attract their attention in learning because these materials can support the natural use of language in the classroom contexts. To create a communicative classroom, teachers should design their classroom activities to allow students to engage and interact with peers in pair and group work in various tasks.

\section{Conclusion}

CLT has been used worldwide in a number of language classrooms and it evidently remains beneficial in English language teaching and learning despite a need for more empirical research on CLT utilization in other contexts. It enhances the learners' communicative skill as the principal goal of CLT is to achieve communicative competence. This urges teachers to prepare their lesson plans, teaching materials and classroom activities to help learners develop their skills effectively. It is also known for instructional practice that emphasizes learners' competence regarding social interaction. Students can learn how to use authentic communication with classmates through various activities to enhance their communicative skill. Most importantly, CLT highlights the teacher' role as facilitator in the classroom who supports students' communicative skill development. With the successful application of CLT, it is apparent that teachers and learners can both contribute to effective language teaching and learning concurrently.

\section{References}

Allwright, R. (1979). Language Learning through Communication Practice. In C. I. Brumfit and K. Johnson (eds.): The Communicative Approach to Language Teaching. Oxford: Oxford University Press, pp. 167-181.

Brown, H. D. (2007). Principles of Language Learning and Teaching (Fifth Edition). New York: Pearson Education. Brumfit, C. (1994). Understanding, language and educational processes. In Brown, G., Malmkjaer, K., Pollitt, A. and Williams, J., Language and Understanding, Oxford: Oxford University Press.

Celce-Murcia, M. (2001) Teaching English as a Second or foreign Language. 3rd Edition. Heinle \& Heinle Publisher: Boston.

Dörnyei, Z., \& Ushioda, E. (2009). Motivation, Language Identity and the L2 Self. Buffalo, NY : Multilingual Matters. Ellis, R. (2003). Task-based Language Learning and Teaching. Oxford: Oxford University Press.

Johnson, K. (1996). Language teaching and skill learning. Oxford: Blackwell.

Krieger, D. (2005). Teaching debate to ESL students: A six-class unit. The Internet TESL Journal, 11(2). 
Larsen-Freeman, D. (200o). Techniques and Principles in Language Teaching. Second Edition. Oxford: Oxford University Press.

Littlewood, W. (2007). Communicative and task-based language teaching in East Asian classrooms. Language Teaching, 40 (3), pp. 243-249.

Long, M. (200o). Focus on form in task-based language teaching. In R.D. L ambert \& E. Shohamy (Eds.), Language Policy and Pedagogy: Essays in honor of A. Ronald Walton. Philadelphia: John Benjamin.

Lu, D., \& Ng, J. Y. F. (2013). The Pedagogical Maze: Retrospection on CLT in Hong Kong. Open Journal of Modern Linguistics, 2, pp. 289-294.

Luoma, S. (2004). Assessing speaking. Cambridge, UK: Cambridge University Press.

Richards, J. C., \& Rodgers, T. S. (2014). Approaches and methods in language teaching. Cambridge: Cambridge University Press.

Rubin, J., \& Thompson, I. (1994). How to become a more successful language learner. Boston, MA: Heinle \& Heinle.

Savignon, J.S. (2006). Beyond communicative language teaching: What's ahead? Journal of Pragmatics, 39(1), pp. 207-220

Shrum, J.L. \& Glisan, E.W. (2005). Teacher's Handbook: Contextualized Language Instruction. Boston: Thomson Heinle.

Somdee, M., \& Suppasetseree, S. (2012). Developing English Speaking Skills of Thai Undergraduate Students by Digital Storytelling through Websites. Retrieved March 11, 2020, from http://www.litu.tu.ac.th/journal/FLLTCP/Proceeding/166.pdf

Thornbury, S. (1996). Teachers research teacher talk. ELT Journal, 5o(4), pp. 279-289.

Ward, H. (2017). Teachers rate soft skills as more important than good grades. Retrieved 12 March 2020 from https://www.tes.com/news/teachers-rate-soft-skills-more-important-good-grades

Widdowson, H. G. (2003). Defining issues in English language teaching. Oxford: Oxford University Press.

Young, R. F. (2008). Language and interaction. London and New York: Routledge.

Zheng, Z. (2004). Communicative competence and strategic competence. Sino-Us English Teaching, 1(10), pp. 7075 . 